UNIO - EU Law Journal. Vol. 6, No. 2, July 2020, pp 77-87.

®2020 Centre of Studies in European Union Law

School of Law - University of Minho

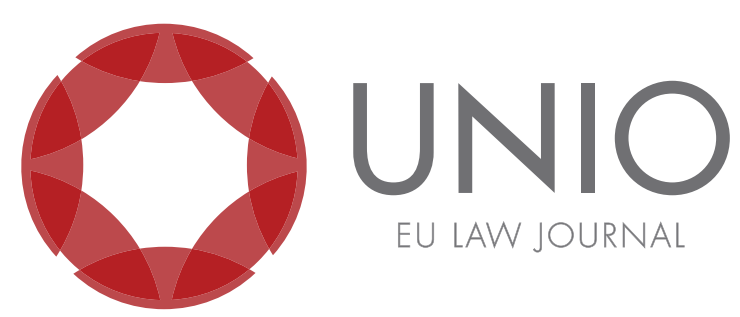

\title{
World Health Organization guidelines, the COVID-19 pandemic, and transnational law
}

\author{
Carla Piffer* \\ Paulo Márcio Cruz**
}

ABSTRACT: The reflections within this paper discuss the importance of transnational law, following the onset of the COVID-19 pandemic. In addition, considerations are made about the transnational law produced by the World Health Organisation ("WHO") against COVID-19. Also, an analysis will be made of the central categories and their relationship with the prefix "trans" and transnational law. Subsequently, the WHO as an entity is discussed along with its emergence and performance in the elaboration of a transnational legal framework, which is to be considered when internalising its guidelines by each Member State. In the context of final considerations, it is emphasised that, in addition to the importance that should be attributed to transnational law, the work of WHO, as a transnational actor, practices materialised acts such as transnational law, both in terms of guidance and in connection with public health matters. The methodology used was based on the inductive method, using the bibliographic research.

KEYWORDS: coronavirus - pandemic - transnational law - World Health Organization.

\footnotetext{
* PhD in Legal Science [University of Vale do Itajaí (UNIVALI), Brazil] and PhD in Public Law (Università degli Studi di Perugia, Italy). Professor of Legal Science at UNIVALI.

** PhD in Public Law [Federal University of Santa Catarina (UFSC), Brazil]. Professor of Legal Science at UNIVALI.
} 


\section{Introduction}

The novel coronavirus disease ("COVID-19") has rapidly spread worldwide. It gained pandemic status, and is currently affecting, without distinction, the most (and the least) important world powers. We are facing a global public health crisis with unprecedented economic effects. We fear something that, in fact, cannot be seen.

Faced with a context of uncertainties, the goal of the present study was to discuss the importance of transnational law in view of the occurrence of transnational phenomena - such as the current COVID-19 pandemic - analysing the transnational law to be applied by States, based on the guidelines provided by the WHO for managing COVID-19.

Initially, we address the categories "endemic", "epidemic", and "pandemic" to determine the connection between the prefixes "pan" and "trans", and the relationship with transnational law. Subsequently, we present a brief outline on the emergence of the WHO and its performance in the elaboration of a transnational legal framework to be taken into consideration by each Member State when implementing WHO guidelines. The methodology used was based on the inductive method, using the reference, category and operational concepts techniques, and bibliographic research.

\section{A reflection on the categories}

From the second half of modernity, since infectious diseases began to have endemic, epidemic, or pandemic characteristics, the bases for combating them started to have fundamentally transnational characteristics. Especially from the beginning of the $20^{\text {th }}$ century, at a time when many cases of infectious diseases began to be registered in the control systems of official health agencies, these facts started to gain visibility through the media, which began to report on the existence of endemics, epidemics, and the consequent risk of pandemics. ${ }^{1}$ In the case of the present study, it was important to establish the concepts of each of these categories.

These diseases, in some cases, are endemic, i.e., when a certain number of cases occurs historically in a specific region. When this endemic level is surpassed, that is, when there is an increase in the historical case curve, it is correct to affirm that there is an outbreak or epidemic. However, the distinction between epidemic and endemic ${ }^{2}$ cannot be made based only on the greater or lesser incidence of a certain disease on a population. What defines the endemic character of a disease is the fact that it is the same for a population, country, or region. ${ }^{3}$

A pandemic outbreak of a disease incorporated into the medical glossary from the $18^{\text {th }}$ century ${ }^{4}$ onwards, being an epidemic of worldwide proportions, is characterised by the emergence of cases in several countries from different continents. The term "pandemic", originating from the neutral prefix "pan", which indicates the idea of

\footnotetext{
1 Eugenio Scannavino, “O apocalipse moderno são as viroses; e o pior está por vir", Folha de São Paulo, March 20, 2020, accessed March 30, 2020, https://www1.folha.uol.com.br/ empreendedorsocial/2020/03/o-apocalipe-moderno-sao-as-viroses-e-o-pior-esta-por-vir.shtml.

${ }^{2}$ Rezende, quoting Bailly (Dictionnaire grec-français, 16. cd. Paris. Lib. Hachette, 1950), states that "The very etymology of the word endemic denotes this attribute. Endemos, in classical Greek, means 'native to a country, indigenous", 'referring to a country", 'found among the inhabitants of the same country"'. Joffre Marcondes de Rezende, "Epidemia, endemia, pandemia. Epidemiologia”, Revista de Patologia Tropical, v. 27, no. 1 (1998): 153, accessed March 20, 2020, https://www.revistas.ufg.br/iptsp/article/view/17199/10371.

${ }^{3}$ Rezende, "Epidemia, endemia, pandemia", 153.

${ }^{4}$ Rezende, "Epidemia, endemia, pandemia", 154.
} 
everything, entirely, and "demos" (people) was used for the first time by Plato, in his book Laws - XI. ${ }^{5}$

This way, it is possible to link the prefix "pan" to the prefix "trans", suggesting the existence of a certain issue, occurrence, or phenomenon between and beyond countries. They are different; however, if we consider that pandemic, as in the case of the present study, indicates the occurrence of cases in numerous places, it becomes a transnational phenomenon. Consequently, it should prompt transnational action, i.e., the two prefixes are complementary, especially when it comes to "cause" (pan) and "effect/reaction" (trans).

\section{The World Health Organization and its transnational character}

Since the $19^{\text {th }}$ century, numerous attempts have been made to create institutionalised mechanisms for providing technical cooperation, especially among the European powers at that time. Throughout the $20^{\text {th }}$ century, specifically in the periods after the great wars and the Cold War, the world witnessed the flourishing of several reorganised or formally created international organisations or bodies. The subjects of their constitutive treaties began to outline the deliberation of common global agendas, involving topics on security, world peace, economy, work, free trade, environment, and health, among many others.

The engagement of efforts in favor of common interests, enhanced by major world episodes, such as the great wars and the end of the Cold War, has demonstrated the central core of the creation and functioning/maintenance of international organisations.

Specifically, regarding health, several attempts have been made since the $19^{\text {th }}$ century to organise an international institution for addressing world health problems. ${ }^{6}$ It is true that there are disagreements with respect to the reasons for the emergence of forums and international cooperation bodies for achieving consensus concerning health and strategic actions for the control and prevention of diseases. However, there is also consensus on the fundamental factor that justifies the creation of this organism, i.e., the growing flow of goods and individuals - which results from the industrialisation and the expansion of markets in urban centers - and its relationship with the increase in diseases. ${ }^{7}$

\footnotetext{
${ }^{5}$ Platão, As Leis, trans. Edson Bini (Bauru: Edipro, 1999).

${ }^{6}$ The outline of these organizations began in Europe in 1851, twenty years after the outbreak of cholera, when Paris hosted the first International Health Conference, with the aim of reaching an agreement between twelve States on the minimum requirements for maritime quarantine, in order to "provide important services to trade and navigation". WHO - World Health Organization, Les dix premières années de L'Organisation Mondiale de la Santé (Geneva: WHO, 1958), 06. In 1892, this consensus was adopted, but restricted to cholera only. In Latin America, due to the impact of the cholera and yellow fever epidemics, a health convention was held in Montevideo in 1873, with the presence of Brazilian, Argentine and Uruguayan health authorities, determining common measures to prevent Asian cholera and yellow fever, plague, and typhus. Other efforts have been made to reach consensus on the prevention and classification of diseases, as well as on the organization of international health institutions. Among the main ones, the WHO cites the International Sanitary Bureau in 1902, based in Washington (USA) and currently known as the Pan American Health Organization (PAHO); the Office International d'Hygiène Publique (OIHP), in Paris (1907); and The Health Organization of the League of Nations, based in Geneva, Switzerland (1919). Nísia Lima, "Brazil and the Pan American Health Organization: a history in three dimensions", in Public Health Pathways in Brazil, ed. Jacobo Finkelman (Rio de Janeiro: Ed. Fiocruz), 23-116.

${ }^{7}$ Lima, "Brazil and the Pan American Health Organization".
} 
Thus, the WHO was created in 1946, governed by the Constitution of the World Health Organization, in force since 7 April 1948. ${ }^{8}$ Its preamble asserts that; "The Member States of this Constitution declare, in accordance with the Charter of the United Nations, that the following principles are fundamental for the happiness, harmonious relations, and security of all peoples [...]"?

Currently, composed of 194 States, as a member of the United Nations (UN) system, it is one of the most decentralised organizations in the family, ${ }^{10}$ entrusting its six regional offices (Africa, the Americas, Southeast Asia, Europe, the Eastern Mediterranean, and the Western Pacific) the formulation of guidelines for the respective regions, as well as the execution of the decisions of the headquarters, located in Geneva (Switzerland). ${ }^{11}$

In addition to its vast geographical scope, the WHO occupies a unique position in global health, thanks to its visionary official charter - called the Constitution, which is unusual in the UN system - ensuring a social approach to health, and affirming it as a human right. ${ }^{12}$ The Human Rights discourse was the tool used by the WHO to face the usual restrictions of diplomacy of the States, ${ }^{13}$ although much remains to be done in this regard.

In this context, the UN, through its organisations such as the International Labor Organization (ILO), the World Trade Organization (WTO), and the WHO, for example, is essentially of a transnational character. It provides regulations and guidelines that are internalised by the Member States, which, since decades, began to create a framework of legal rules of transnational nature.

\section{Transnational law and the World Health Organization}

As we have already mentioned a considerable number of times, ${ }^{14}$ addressing transnational law means referring to the classic work of American diplomat, scholar and jurist Philip C. Jessup, dating from 1956. Just over a decade after the end of World War II, and experiencing a unique historical moment of improvement and intensification of relations between States, this author was emphatic in affirming that the States are not the only group that interests us, and that the term "international" is misleading, since it suggests that we concern ourselves only with the relationships

\footnotetext{
${ }^{8}$ On April 7, 1948, the WHO Constitution came into force with the ratification of the participation of 26 of the 61 member countries. During the First World Health Assembly, held in Geneva, delegations from 59 governments became members of the WHO. Then, April $7^{\text {th }}$ became World Health Day, celebrated every year.

9 WHO - World Health Organization, Constitution of the World Health Organization, New York, 1946, accessed March 18, 2020, http://www.direitoshumanos.usp.br/index.php/OMS-Organiza $\% \mathrm{C} 3 \% \mathrm{~A} 7 \% \mathrm{C} 3 \% \mathrm{~A} 3 \mathrm{o}-\mathrm{Mundial}-\mathrm{da}-\mathrm{Sa} \% \mathrm{C} 3 \% \mathrm{BAde} /$ constituicao-da- world-health-organization-omswho.html.

${ }^{10}$ Fiona Godlee, "The World Health Organization: WHO in crisis", BMJ - British Medical Journal, no. 309 (1994): 1424-1429.

11 “Countries", WHO - World Health Organization, accessed March 18, 2020, https:/ /www.who.int/ countries/en/.

${ }^{12}$ David Legge, "Future of WHO hangs in the balance", BMJ - British Medical Journal, no. 345 (2012), accessed March 18, 2020, https://www.bmj.com/content/345/bmj.e6877.full.

${ }^{13}$ João Biehl and Adriana Petryna, "Critical global health", in When people come first - critical studies in global health, ed. João Biehl and Adriana Petryna et al. (Princeton: Princeton University Press, 2013), 12.

${ }^{14}$ Carla Piffer and Paulo Márcio Cruz, "O direito transnacional como disciplina em cursos jurídicos", in UNIO/CONPEDI E-book 2017. Interconstitucionalidade: democracia e cidadania de direitos na sociedade mundialatualização e perspectivas, v. II, coord. Alessandra Silveira (Braga: CEDU/EDUM, 2018), 37-58.
} 
between a Nation (or State) and other Nations (or States). ${ }^{15}$ Other authors, such as Vagts, Steiner and Koh, ${ }^{16}$ also followed Jessup's trend, evolving the analysis of the topic gradually, as the world society itself started to face transnational demands, occurrences, and legal issues.

With the development of globalisation, transnationality, as a phenomenon, started to be observed in a hyaline way. It was highlighted as manifestations of transnationality, ${ }^{17}$ or transnationality as a reflective phenomenon of globalisation. ${ }^{18}$ New manifestations of globalisation, different forms of belonging to sociocultural and political arrangements, ${ }^{19}$ deterritorialisation, ${ }^{20}$ difficulty in relating the phenomenon to a given territory, reconfiguration of cultural identities, and new social and economic agents, among other factors, demonstrate that the edge has already crossed national borders.

At this point, it is worth recalling the five points of convergence that demonstrate some of the main characteristic features of transnational relationships that compose transnationality, namely: (i) horizontal relationships; (ii) constant and influential relationships; (iii) disruption of the State unit; (iv) network of legalities; and (v) weakening of control and social protection systems.

As a result, the more the phenomenon is consolidated, the more evident is the need to accept the existence of transnational law. This mechanism has a unique feature, i.e., the untying of the production of autonomous political norms in a fragmented world society, as pointed out by Teubner. ${ }^{21}$ Instead of the hierarchy and unity of Law in the Constitutional State, attention is drawn to the heterarchical plurality of legal orders, ${ }^{22}$ among them those produced by international organisations.

Still, according to Teubner, supra and transnational orders (public and private) bring elements of complexity to the legal systems. This way, already pacified assumptions of modernity should necessarily be reread. The evaluation of Law in globalisation proposes the existence of a diversity of "global civil constitutions", in specific sectoral spheres, often outside the policy exercised by the States, therefore treated in a wrong way by the classic division between public international law and private international law. ${ }^{23}$

In this way, transnational law does not emanate from a single "will-forming" center, but is produced by a multiplicity of simultaneous decisions, which, according

\footnotetext{
${ }^{15}$ Philip Jessup, Transnational law (São Paulo: Fundo de Cultura, 1965).

${ }^{16}$ H. J. Steiner and D. F. Vagts, Transnational legal problems: materials and text, 2. ed. (New York: The Foundation Press, 1976).

${ }^{17}$ Carla Piffer and Paulo Márcio Cruz, "Manifestações da transnacionalidade e do direito transnacional", in Transnacionalidade e sustentabilidade: dificuldades e possibilidades em um mundo em transformação, ed. Guilherme Ribeiro Baldan, Carla Piffer and Paulo Márcio Cruz (Porto Velho: Emeron, 2019).

${ }^{18}$ Piffer and Cruz, "O direito transnacional como disciplina", 38.

${ }^{19}$ Gustavo Lins Ribeiro, As condições da transnacionalidade (Brasília: Universidade de Brasília, 1997), 03.

${ }^{20}$ Joana Stelzer, "O fenômeno da transnacionalidade e sua dimensão jurídica”, in Direito e transnacionalidade, ed. Joana Stelzer and Paulo Márcio Cruz (Curitiba, Juruá, 2009), 25.

${ }^{21}$ Gunter Teubner, "A bukowina global sobre a emergência de um pluralismo jurídico transnacional", Impulso, v. 14, no. 33 (2003): 9-32.

${ }^{22}$ Gunter Teubner, "The corporate codes of multinationals: company constitutions beyond corporate governance and co-determination", in Conflict of laws and laws of conflict in Europe and beyond: patterns of supranational and transnational juridification, ed. R. Nickel (Oxford: Hart, 2009).

${ }^{23}$ Gunter Teubner, "Fragmented foundations: societal constitutionalism beyond the Nation State", in The Twilight of Constitutionalism?, ed. P. Dobner and M. Loughlin (Oxford: Oxford University Press, 2010), 331-332.
} 
to Teubner, should be called "polycentric law". ${ }^{24}$ Therefore, it is no longer possible to understand such concepts in their classic versions if they are still operational concepts to describe this institutional experience. ${ }^{25}$

Consequently, new power and competition relations have been observed, and new factors of incompatibility between the social agents and the State units started to be put to the test on a daily basis, making Law adapt to the new events, ${ }^{26}$ because Law is a social fact or phenomenon; it does not exist without society, and cannot be conceived outside of it. ${ }^{27}$

This pluralism of legal orders involves State and non-state agents beyond the limits of the States that are not fully able to conduct official international legal acts, given that legal reflexes of transnational relations are not limited to economic issues. Litigation involving human rights - and consequently health-related issues environmental issues, transnational governance acts, transnational social organisations, labour relations, family relations, public or private contracts, and many other legal and non-legal areas compose the current transnational legal pluralism. ${ }^{28}$

Specifically, with regard to the role of the WHO as a transnational agent, an ongoing debate involves two factors, namely: $i$. whether this international body should be predominantly a normative agency, setting standards, developing protocols, and providing information that can be used by governments and agencies when implementing their programs; or ii. the extent to which it should be involved in implementing its own programs. ${ }^{29}$

The answer to this question should be given considering the phenomenon of transnationality and the plurality of agents inserted in unique socio-political and legal contexts. It is worth mentioning that, in both cases, the WHO plays the role of transnational agent and contributes to the production of health-related transnational law.

The characteristics of transnational agent relating to this organisation are evidenced by standardising health actions and policies worldwide, offering guideline and protocol manuals, advising member countries on the execution of health policies and programs, implementing actions, intervening in the fight against diseases and inequalities that affect the health status of populations, preparing global health reports, and defining their implementation by the health systems of the Member States. The production of transnational law in this area becomes evident at the moment when the Member States produce their internal regulations based on guidelines issued by the WHO.

The goal of the present study is in line with one of the binding documents produced within the scope of the WHO, known as International Health Regulations

\footnotetext{
${ }^{24}$ Teubner, "Fragmented foundations", 332.

${ }^{25}$ José Luiz B. de Morais, As crises do Estado e da Constituição e a transformação espaço-temporal dos direitos bumanos (Porto Alegre: Livraria do Advogado, 2011), 12.

${ }^{26}$ Carla Piffer and Paulo Márcio Cruz, "O direito transnacional e a consolidação de um pluralismo jurídico transnacional”, in Interfaces entre direito e transnacionalidade, ed. Heloise Siqueira Garcia and Paulo Márcio Cruz (Itajaí: AICTS, 2020), 35.

${ }^{27}$ Miguel Reale, Liç̃es Preliminares de Direito (São Paulo: Saraiva, 2020).

${ }^{28}$ Piffer and Cruz, "O direito transnacional e a consolidação de um pluralismo jurídico transnacional", 40.

${ }^{29}$ Michael McCarthy, "What's going on at the World Health Organization?”, The Lancet, v. 360, no. 9 (2002): 340, accessed March 20, 2020, https://www.thelancet.com/action/showPdf?pii$=\mathrm{S} 0140-6736 \% 2802 \% 2911243-8$.
} 
(IHR). ${ }^{30}$ This document was prepared by all Member States and established rules to be applied by countries in order to stop the spread of epidemics. In $2005,{ }^{31}$ this Regulation was extended by including new diseases to the list of the 1995 IHR.

As a demonstration of the transnational aspect of the topic, the IHR included new concepts and categories that re-dimensioned international disease control, establishing an approach that covers all possible risks, regardless of their source or origin. It established the terminology "public health emergency of international concern" (PHEIC), and made Member States responsible for notifying the WHO about "all events in their territories that might constitute a PHEIC". ${ }^{32}$ In addition, it is worth noting that the issues addressed in the IHR have been constantly discussed in order to adapt them to the current world reality. ${ }^{33}$

As a way of internalising the referred document, Brazil started to adapt the existing national structures and resources to meet the requirements of basic issues in accordance with the IHR - such as those related to surveillance activities, reports, notifications, verification, response, and collaboration in the activities involved in each topic included in the Regulation. This fact was demonstrated by the Ministry of Health 2016 National Focal Point Operation Plan for the 2016 IHR. ${ }^{34}$ Likewise, similar action was expected from the other Member States.

The importance of the performance of a transnational agent and the elaboration of a transnational legal framework on health today is justified given the occurrence of a PHEIC. The projection of articulated actions involving the Member States promoted by the WHO demonstrates the need for engagement of the entire planet in the face of the occurrence of the coronavirus pandemic, an issue that will be addressed next.

\section{The COVID-19 pandemic and the transnationality phenomenon}

The $15^{\text {th }}$ edition of the Global Risk Report presented at the World Economic Forum, in Davos, Switzerland, which took place in January 2020, indicated that health systems were under new pressures around the world in the face of vulnerabilities

\footnotetext{
${ }^{30}$ The International Health Regulations (IHR) is a binding international legal instrument for 196 countries worldwide, which includes all Member States of the WHO Its goal is to help the international community prevent and respond to serious public health risks that have the potential to cross borders and threaten people around the world.

${ }^{31}$ The IHR came into effect on 15 June 2007. At that time, all Mercosur countries had already ratified these regulations.

32 David Fidler, "From International Sanitary Conventions to Global Health Security: the new international health regulations", Chinese Journal of International Law, v. 4, no. 2 (2005): 362.

33 On May 18, 2017, the World Health Assembly, presented Document A70/16, with the Global Implementation Plan of the IHR, which comprises six areas of action, the first of which, "Accelerating State Parties' implementation of the International Health Regulations (2005)", includes the elaboration of a "five-year global strategic plan to improve public health preparedness and response", to be submitted to the World Health Assembly in May 2018 (A70/16). Barbara Frossard Pagotto, "Regulamento sanitário internacional (RSI 2005) na agenda de cooperação em saúde do Mercosul e a emergência do virus zika”, accessed March 20, 2020, https://portalarquivos2.saude.gov.br/images/ pdf/2018/outubro/22/12_Barbara_Pagotto.pdf.

${ }^{34}$ Brasil, Ministério da Saúde, Secretaria de Vigilância em Saúde, Departamento de Vigilância das Doenças Transmissíveis, Plano de operação do ponto focal nacional para o regulamento sanitário internacional (Brasília: Ministério da Saúde, 2016), accessed March 21, 2020, http://bvsms.saude.gov.br/bvs/ publicacoes/plano_operacao_ponto_focal_nacional_regulamento_sanitario_internacional.pdf.
} 
resulting from changing social, environmental, demographic, and technological practices and habits. Indeed, this is an accurate finding.

With the recent declaration of the COVID-19 pandemic by the WHO, two months after the referred report, the issues addressed in it were fully confirmed. According to the statement by the WHO Director-General, Tedros Adhanom: "we are all affected by the growing COVID-19 pandemic. It is an unprecedented health challenge, and we know that people and organizations everywhere want to help. The WHO is leading and coordinating the global effort, supporting countries to prevent, detect, and respond to the pandemic". ${ }^{35}$

If we go back to the characteristics of the transnationality phenomenon, we will realise that a pandemic - like the one occurring today - can be described as an infectious disease that spreads among populations located in extensive geographic regions, for example, a continent, or even the planet Earth, in a transnational manner.

As with many phenomena of transnational scope (migration, environmentrelated issues, crime, economics, etc.), the current COVID-19 pandemic knows no borders, does not respect sovereign States, or world economic powers, and does not differentiate between races or social classes; it simply crosses the territorial boundaries established after the Westphalia Treaty. In addition, it pierces, frightens, and causes the most feared damage, the materialisation of the risk of risks, ${ }^{36}$ i.e., the loss of thousands and thousands of lives.

For more than a decade, studies on transnationality and transnational law have been conducted in the Master's and PhD in Legal Science of the University of Vale do Itajaí (UNIVALI), Santa Catarina, Brazil. These studies have called attention to the fact that the intense changes occurring in the current risk society also require new political and legal sciences strategies. ${ }^{37}$

Furthermore, in 2007, Miglino ${ }^{38}$ stated that the ecological problem would probably lead to the creation of transnational power centers, going beyond the ideology and legal structure of international relations. However, many scholars disagreed. Today, the question is: Who will disagree with the need of transnational power centers targeted at maintaining life? It is difficult to find a more consistent argument than this one.

However, as a response to the current COVID-19 pandemic, States began to close in on themselves, restricting their territorially - in a non-uniform and unplanned manner - without taking into consideration any possibility of global cooperation in favour of the most essential common interest, i.e., the maintenance of life. The principle of solidarity in the face of common axiological guidelines, materialised by cooperation, and invoked repeatedly in the international arena, has

35 "La OMS, la Fundación pro Naciones Unidas y sus asociados ponen en marcha el Fondo de Respuesta Solidaria a la COVID-19”, WHO - World Health Organization, accessed March 25, 2020, https://www.who.int/es/news-room/detail/13-03-2020-who-un-foundation-and-partners-launchfirst-of-its-kind-covid-19-solidarity-response-fund.

${ }^{36} \mathrm{It}$ is appropriate to recall Beck's words about knowledge in the Risk Society and the importance of health: "Certainly, "health" is also a very high cultural value, but it is (more than that) precisely the presupposition of life. The universalization of health creates threats that are always present and, sometimes, affect the economic and political system. So, here, cultural and social premises are not the only jeopardized factors, which with one can live, just like the way of modernity shows, despite all the tears that have already been shed'. Ulrich Beck, O que é globalização? Equivocos do globalismo. Respostas à globalização (São Paulo: Paz e Terra, 1998), 92.

${ }^{37}$ Paulo Márcio Cruz and Maurizio Oliviero, "Reflexões sobre o direito transnacional", Revista Novos Estudos Jurídicos, v. 17, no. 1 (2012): 25.

${ }^{38}$ Arnaldo Miglino, "Una comunidade mundiale per a tutela dell' ambiente", Revista Archivo Giuridico, v. CCXXVII, no. IV (2007). 
always seemed inadequate, not to say unnecessary. It is worth mentioning that the same effect might be related to transnational law. In a recent study on the current pandemic, Ferrajoli pointed out to the "[...] dramatic confirmation of the need and urgency of achieving a planetary constitutionalism [...]". This author also mentions the need for effective and homogeneous measures to be adopted targeted at preventing the variety of procedures performed - in many cases completely inadequate - from favoring infection and multiplying the damage for everybody. ${ }^{39}$

In the case of Europe, the whole legal apparatus involving European law, and divergent measures to combat the pandemic were adopted, mainly by its former Member, the United Kingdom. An example of this was the strategy adopted in midMarch this year by the British government: it was based on the "mitigation" of the pandemic and the "herd immunisation", or infection of a large part of the population, which in theory would develop collective immunity with the goal of protecting all citizens. ${ }^{40}$ However, given the possibility of the disease spreading rapidly across the country and drastically impacting the public health system, the strategy was changed, and the lockdown was decreed a few days later.

Italy, at the beginning of March, was the second country most affected by COVID-19, behind only China. In view of this situation, the country extended exceptional protection measures to the entire country as of March 9, according to the Decree of the President of the Council of Ministers. ${ }^{41}$ Afterwards, countries with Spain, France, the United Kingdom overcame the barrier of 25,000 deaths by COVID-19 in May this year. ${ }^{42}$

However, taking into account the need to adopt measures that take into account cooperation, world interdependence, global community, or the fact that global problems are transnational challenges and demand global responses, the European Union has started to develop an action program, which it had commenced in February this year.

In the case of the European Union, in the first days of February, the first repatriations by air from France and Germany, co-financed by the EU Civil Protection Mechanism, brought home 447 European citizens, from Wuhan. ${ }^{43}$

Faced with the advance of the pandemic, as an evident transnational event, by 31 March, the Commission already approved several schemes based on the Temporary Framework worth several hundred billions of Euros to support Member States 'economies in view of the impact of the coronavirus outbreak. It took 18 decisions approving 27 national measures, and days later, proposed the activation of the fiscal framework's general escape clause to respond to pandemic which, once endorsed by the Council, it will allow Member States to undertake measures to deal

\footnotetext{
${ }^{39}$ Luigi Ferraroli, "The virus met the globalizzazione with piedi per land", il manifesto, accessed March 22, 2020, https:/ /ilmanifesto.it/il-virus-mette-la-globalizzazione-con-i-piedi-per-terra/.

40 "Coronavírus: o que diz modelo matemático que levou Reino Unido a mudar radicalmente combate à Covid-19”, BBC News Brazil, accessed October 20, 2020, https://www.bbc.com/portuguese/ internacional-51944800.

41 "Coronavirus, la normativa vigente", Italia, Presidenza del Consiglio dei Ministri, accessed October 20, 2020, http://www.governo.it/it/coronavirus-normativa.

${ }^{42}$ Compared to 54.42 deaths per 100,000 inhabitants recorded in Spain, 48.12 in Italy, 37.63 in France or 43.33 in the United Kingdom, Poland records 1.84; Slovakia 0.46; Czech Republic 2.37; Hungary 3.59; Austria 6.78 and Romania 4.20 (figures from Johns Hopkins University on May 6, 2020). "Coronavírus", BBC News Brazil.

43 “Timeline of EU action”, European Commission, accessed October 20, 2020, https:/ / ec.europa. eu/info/live-work-travel-eu/health/coronavirus-response/timeline-eu-action_en.
} 
adequately with the crisis, while departing from the budgetary requirements that would normally apply under the European fiscal framework. ${ }^{44}$

It is worth mentioning that there were countless actions by the European Union in its performance and intervention in the pandemic. Since January, funds were mobilised for research on the new coronavirus outbreak and also the EU civil protection mechanism activated for the repatriation of EU citizens.

Even today, mid-October 2020, faced with a second wave of contagions, the EU is making efforts of the most varied orders: the European Covid-19 data platform to enable the rapid collection and sharing of available research data; the Commission joined the Covid-19 Vaccine Global Access Facility; the plans for purchasing vaccines; co-hosted the first meeting of the High Level Facilitation Council; the EU is leading the work of the global collaborative framework Access to Covid-19 Tools Accelerator (the ACT-A) to speed up the development and deployment of vaccines, tests and treatments against COVID-19, as well as to improve health systems, ${ }^{45}$ among other actions. ${ }^{46}$

It appears, therefore, the sense of transnational law, "applied by institutions with bodies and organizations for governance, regulation, intervention $[. .$.$] ", { }^{47}$ and the joint action of the transnational bodies, European Union and organisations become feasible and indispensable in the face of the current facts. From the establishment of "transnational public spaces", 48 the existing transnational health law, within the scope of the WHO, becomes the instrument for guiding transnational powers, with the intensification of the processes of abdicating the sovereign powers of States.

Currently, more than before, there is a call for recognition and respect for a world society affected, without distinction, by challenges arising from transnational phenomena - to which the current COVID-19 pandemic is now added. At this moment, we cannot forget Beck's teachings regarding the dependence relations between national States - as territorial states with their power founded on the link with a given space - and world society, given that it relativises and interferes with the performance of those States, "[. ..] because an immense variety of connected places cross their territorial borders, establishing new social circles, communication networks, market relations, and forms of coexistence. [... $]^{349}$

Transnational law, applied by States based on the WHO guidelines against COVID-19, together with the establishment of urgent planetary action guided by transnational networks of cooperation and solidarity, offers effectiveness and efficiency to new global transnational governance strategies targeted at controlling and combating the COVID-19 pandemic.

Therefore, this global society affected by transnational problems requires the consolidation of transnational law, initially produced by the WHO guidelines, and oriented by cooperation in solidarity actions. The world market and large transnational companies know that they are able to produce and distribute medical equipment and health materials. Countries that may be less affected, or better prepared to

\footnotetext{
44 "Timeline of EU action", European Commission.

45 "Coronavirus Global Response: WHO and Commission launch the Facilitation Council to strengthen global collaboration", European Commission, accessed October 20, 2020, https:// ec.europa.eu/commission/presscorner/detail/en/ip_20_1581.

${ }^{46}$ For more information visit: "Timeline of EU action", European Commission.

${ }^{47}$ Cruz and Oliviero, "Reflexões sobre o direito transnacional", 22.

${ }^{48}$ Cruz and Oliviero, "Reflexões sobre o direito transnacional", 22.

${ }^{49}$ Beck, O que é globalização?, 18.
} 
deal with the current pandemic, could send health professionals to those most in need. The global economy, guided by its important agents, could create adequate economic policies, thus contributing to mitigate the economic damage caused, and avoiding numerous social problems. This way, it would be possible to establish the transnational public spaces that society needs.

\section{Final remarks}

The goal of the present study, conducted in the midst of the COVID-19 pandemic, was to emphasize the importance of transnational law in the face of a transnational phenomenon of this nature, with proportions that cannot yet be estimated, and with all due respect to international law, as we already know that this is a step forward. This perspective means no longer Law between States, but Law created from transactional issues by the States.

Using the classification of "pandemic" instead of "endemic" opens the possibility and, above all, denotes the need of coordinated and joint application of the WHO guidelines by its Member States, under the form of transnational law to be internalised individually against COVID-19.

It is worth noting that the WHO, issuing protocols, recommendations, and standards in the face of a pandemic, allows the States, under the same basis of guidance, to edit their own internal rules and materialise the transnational law that will guide and link public health actions.

It is evident that this transnational law, created from the scope of a transnational agent, should also be permeated by transnational networks of cooperation and solidarity. This fact will make it possible to provide the due degree of efficiency to global strategies, recognising the fact that we are dealing with nothing more and nothing less than the preservation of life on a planetary scale. 